\author{
Toplum Bilimleri Dergisi - Journal of Social Sciences \\ ISSN: 1306-7877 e-ISSN: 2147-5644 \\ Aralık / December 2019, $27: 384-404$
}

\title{
İktidar İlişkileri Çerçevesinde Din ve Devlet
}

Religion and State in the Context of Power Relations

\section{Muhittin IMIL}

Milli Savunma Üniversitesi, Kara Harp Okulu Dekanlığı, Sosyoloji Bölümü, Doktor Öğretim Görevlisi National Defense University, Dean of the Turkish Military Academy, Department of Sociology,

\author{
Asst. Prof. Dr. \\ Ankara, Turkey \\ malazgirt2130@gmail.com \\ https://orcid.org/0000-0001-5124-7984
}

\section{Makale Bilgisi / Article Information}

http://dx.doi.org/10.29228/tbd.2007.39960

Makale Türü / Article Types: Araştırma Makalesi / Research Article

Geliş Tarihi / Received: 30 Kasım / November 2019

Kabul Tarihi / Accepted: 26 Aralık / December 2019

Yayın Tarihi / Published: 31 Aralık / December 2019

Yayın Sezonu / Pub Date Season: Aralık / December 2019

Cilt / Volume: 27

Sayfa / Pages: 384-404

Copyright (C) Published by Toplum Bilimleri Dergisi - Journal of Social Sciences. All rights reserved. www. toplumbilimleri.com 


\section{İktidar İlişkileri Çerçevesinde Din ve Devlet}

Öz: Din kurumunun topluma temel katkısı, yüksek bir değerler manzumesinin üretimidir. Bu üretim, devrinin muktedirlerine karşı bir meydan okuyuştur aynı zamanda. Sosyolojik literatürde din kurucu karizma olarak ifade edilen peygamber, tanrısal sözü vahyi- toplumla paylaşmaya başladığında eşzamanlı olarak dünyevi otorite ile çatışma da başlar. Yönetim erki, toplumu kendisine rağmen etkisi altına alan potansiyel güç merkezini henüz mümkünken bastırmak isteyecektir. Bu çaba çoğunlukla başarısızlıkla sonuçlandığı için zamanla kurumsal dinin temsilcileriyle yönetici erk arasında çatışma ya da işbirliği temelinde şekillenen uzun soluklu bir ilişki gelişir. Dinin ürettiği değerler manzumesi, söz konusu mücadele boyunca kurumsal dinin temsilcileri tarafından dünyevi iktidar, yönetim tarafından ise uhrevi meşrulaştırma uğruna araçsallaştııılarak içi boşaltılır. Nitel araştırma yöntemlerinden doküman inceleme yoluyla gerçekleştirilen çalışma, güncel görüngüleriyle farklı coğrafya ve kültürlerde söz konusu mücadelenin gösterdiği gelişimi incelemeyi amaçlamaktadır. Araştırma sonucunda incelenen örneklerden yola çımak suretiyle genellikle en kadim yönetimlerden modern devlet yapılarına kadar dini değerler bütününün otorite tarafından araçsallaştırıldığı, kurumsallaşan dinin ise farklı tezahürlerle dünyevi iktidara talip olduğu ortaya çıkmıştır.

Anahtar Kelimeler: Din Sosyolojisi, Sivil Din, Kutsal Devlet, Ruhban, Milli Din.

\section{Religion and State in the Context of Power Relations}

Abstract: The basic contribution of the religious institution to society is the production of a high value range. This production is also a challenge to the powers of its era. When the prophet, expressed in the sociological literature as the founding charisma of religion, begins to share the divine word with society, the conflict with worldly authority begins simultaneously. The governing power will want to suppress the potential power center that has influenced society despite it. As this effort is often unsuccessful, a long-term relationship between the representatives of institutional religion and the governing power, which is based on conflict or cooperation, develops over time. The values produced by religion are evacuated by the representatives of corporate religion during the struggle in question and instrumentalized by the administration for the purpose of legitimizing the otherworldly power. The study, which is carried out through document analysis, which is one of the qualitative research methods, aims to examine the development of the struggle in different geographies and cultures with its current phenomena. As a result of the research, it is revealed that religious values are generally instrumentalized by the authority from the 
most ancient administrations to the modern state structures, while the institutionalized religion aspire to worldly power with different manifestations.

Keywords: Sociology of Religion, Civil Religion, Holy State, Clergy, National Religion.

\section{Gíriş}

İnsanoğlunun en kadim zamanlarında dini ve dünyevi otoriteyi tek başına elinde bulunduran yönetici, zamanla dini otoriteyi kurumsal dinin temsilcilerine devretmek zorunda kalmıştır. İnsanlığın toplumsal gelişim evrelerine koşut olarak biçimlenen bu ikili ilişki biçimi, bazen çatışma bazen de uyuşmanın öne çıtığı bir düzen içinde büyüyüp karmaşıklaşarak günümüze ulaşır. Din ve devlet ilişkisinin farklı yoğunluklardaki biçimlerini, klan-kabile şefliğindeki yönetim erkinden modern devlet yapısındaki yönetim anlayışına kadar görmek mümkündür. Aşkın gücün, görece en karmaşık olanlardan en basitlerine kadar her insan faaliyet ve üretiminde etkin olduğu geleneksel yapılardan, sözde ayaklarının yerden kesilerek gökyüzüne çıkarıldı̆̆ı en seküler toplumlara kadar sosyal yaşantının her anında dini tezahürler mevcuttur. Hatta bugün çok küçük dini tezahürlere rastlamanın son derece güç olduğu seküler toplumlarda bile temelden tepeye kadar devletin yapısı, yasası ve yaptırımlarında kutsal renk tonlarını görmemek elde değildir.

Çalışma, dini çoğulcu, seküler hatta dini yok sayan yönetimlerde bile uhrevi düşüncenin toplumsal ve yönetsel yansımalarını ortaya koymayı, din-devlet ilişkilerini dinin kimlik oluşturma ve meşruiyet kazandırma gücü ile birlikte iktidar talepleri açısından değerlendirmeyi amaçlamaktadır. Bu bağlamda kısaca tarihsel arka plana değinmeye müteakip ABD, Avrupa, Sovyet Rusya ve Türkiye örnekleri, kurumsal dinin sosyal ve siyasal hayata yansımaları açısından irdelenecektir.

\section{DİN VE DEVLET İLIŞKİSININ TARİHSEL ARKA PLANI}

Bireysel ve sosyal idraklerde yerini aldığ1 ilkel zamanlardan itibaren yaşandığı şekliyle tanrısal söz, vaaz edildiği her toplumda yeni bir kültürlenme süreci yaşamış ve farklı dindarlık biçimleri gelişmiştir. Din, dünyaya mal olur ve pratik hale gelirken coğrafya, insani tecrübenin her yeni şekli, adet, gelenek, görenek ve hatta her sosyal kurumla etkileşir. Toplumlar, aynı tanrısal buyruğu farklı tezahürlerle yaşarlar. Bununla birlikte din, temas ettiği her toplumsal tezahüre de kendisinden bir şeyler eklemek suretiyle kutsallık kazandırır. Hatta denilebilir ki dinin toplumsal işlevlerinden en güçlü olanı, temas ettiği her şeye meşruiyet kazandırma gücüdür. Bu güç sosyal düzeni etkileyerek değiştirirken toplumsal düzeni sağlamak üzere kurgulanmış bir yönetim organı olan devleti de 
cazibesiyle etkiler. Öyle ki bu sihirli güç, en ilkel yönetimlerden en modern olanlara, en seküler devlet teşkilatlarından dinin toplumsal hayattan tamamen çıkarılması gerektiğini deklare eden komünist yönetimlere kadar çeşitli şekillerde kullanılmaya çalışılmıştır. Zira otoritenin, toplum ve bireyler üzerindeki tasarruflarının direnç gösterilmeden hayata geçirilmesi için kutsal bir zırhla donanmış olması önemlidir.

Bilinen tarih boyunca ister barışçıl yollardan, isterse zorla olsun dünyevi iktidarın genişlemesi, dinin yayılmasıyla paralellik göstermiştir. Dünyevi iktidar, istila ettiği coğrafyada kılıcının gücü sayesinde dinini yayarak etrafındaki tehditleri azaltmaya, aynılaştırma (asimilasyon) sürecini hızlandırarak yeni toplulukları bir an evvel "biz" dairesinin içine almaya çalışmıştır.

Dinin araçsal-akılcı kullanımındaki faydayı gören yöneticiler, amaçları doğrultusunda hizmet gören din düşüncesini ve ruhbanları istila ordularına eklemlemeye başlarlar. Bu şekilde bir taraftan yayılmacı emeller kutsal bir anlam kazanıp askerlerin savaşma azim ve iradeleri yükseltilirken, eşzamanlı olarak dinin yayılması öngörülmüştür. Ordu Tanrı'nın ordusuna, askerler Tanrı'nın askerlerine ve amaç Tanrı'nın emrini yerine getirmeye dönüşür. İbn-i Haldun'un bu konuda yerinde bir tespiti vardır: "İnsanlar onların yanında, onlara karşı olanlarla savaşırlar. Bu yolla dinsel inançlarını korumuş olacaklarını düşünerek savaşırlar. Onun için de böylesine bir güç kazanmış aileden gelenler, egemenliklerini sürdürebilmek için büyük bir yakınlık bağına gerek duymazlar. Neden ki onlara boyun eğmek Tanrı'nın yazıp gerekli kıldı ̆̆ı bir ödev olmuştur insanlar için. Değişmez ve tersi düşünülmez bir ödev.". ${ }^{1}$

Din, aynı zamanda ilkel yöneticiden beri kullanılan bir yönetsel araç olduğundan aslında din ve devlet ilişkilerinde ayrışma sadece zahiri manada olmuştur. Dünyevi ve uhrevi iktidar en başlarda bir kişide toplanırken ilerleyen zamanlarda ayrışmış, zamanla güç dengeleri değişkenlik göstermiştir. Bu bağlamda uhrevi alan dünyevileşmeye ve dolayısıyla devletin fonksiyonlarına talip olmaya başlarken, dünyevi iktidarın yönetim organı olarak tasarladığı devlet ise kendisine her zaman ve kültürde yüksek seviyede tutmaya çalıştı̆ğ bir kutsallık atfetmiştir.

İktidarın elitleri tarafından araçsallaştırılan kutsal dünyanın temsilcileri olan din adamları, zamanla kurumsallaşarak otoriteyle iktidar savaşına girişmişler, bu iktidar ve egemenlik savaşında Avrupa ortaçağının siyasi zihniyeti Hıristiyanlık etrafında şekillenmiştir. Roma imparatorluk yapısını kutsayan Hıristiyanlık, bir tarafta Papa'nın kontrolü atındaki kutsal otoritenin, diğer tarafta ise Roma İmparatoru'nun bulunduğu ikili siyasi yapının temelini oluşturan Çifte Kılıçlar Doktrini'ni geliştirmiştir. Buna göre aynı

\footnotetext{
${ }^{1}$ İbn Haldun, Mukaddime, trc. Süleyman Uludağ (İstanbul: Dergâh Yayınları, 2007), 374.
} 
kişinin hem kral hem de ruhban olması caiz değildir. ${ }^{2}$ Avrupa düşüncesinin temel sorunsalı haline gelen bu ikili yapı, zamanla milliyetçilik düşüncesi ve ulus-devlet olgusunu da tetiklemiştir.

Kilise ve Papa'nın otoritesi yerine tanrısal prensin ve İncil'in otoritesini koyan reform hareketi, siyasal iktidarın üstünlüğünü meşrulaştırmıştır. Siyasal iktidarın dinsel inançları denetleyen ve dinsel alana da egemen olan bir sifatla yeniden tanımlanması, ruhani otoritenin siyasal iktidara tabi olduğu bir kilise-devlet ilişkisi modeli ortaya çıarmıştır. Reformasyon sonrasında ortaya çıkan, dinsel otoritenin dünyevi otoriteye bağlı olması anlamında bir sekülerleşmedir. Reformasyon'un ulus-devlet sistemi üzerindeki en önemli etkisi kilise ve imparatorluk arasındaki geleneksel birlik fikrini ortadan kaldırmasıdır. Sonuçta devlet fikri merkezi dünya imparatorluğundan ulus devlete, ruhani olandan dünyevi olana doğru kaymaya başlamıştır. Ulus-devletin olgunlaşmasında en önemli tamamlayıcılardan biri olarak Avrupa'da ulusal kiliselerin ortaya çıkışı, Reformasyon'dan sonra tamamlanmıştır. ${ }^{3}$ Sadece "milli kilise", "resmi din" ya da "devlet dini" kavramlarının ortaya çıkmış olması dahi din-devlet ilişkisinin gelecekte de gücü ele geçirme temelinde şekillenmeye devam edeceğinin göstergesidir. Bu bağlamda devlet ve din ilişkilerinin dünyanın farklı coğrafya ve kültürlerinde gerçekleşen tezahürlerini incelemek zihin açıcı olacaktır.

\section{KUTSALLAŞAN DEVLET VE SIVIL DIN: ABD}

Amerika Birleşik Devletleri'nin kısa tarihinin şekillenmesinde dini düşüncenin önemli bir yeri vardır. Zira ülkelerinden yeni dünyaya akın akın gelerek kuruluşunda önemli rol oynayan birey ve topluluklar, başta Avrupa ve Asya'dan genellikle pragmatik gerekçelerle gelmişlerdir. Kimisi altına hücum eden, kimisi ülkesindeki yasal yaptırımlardan kaçan söz konusu toplulukların kahir ekseriyeti bir anlamda gönüllü olarak geride bıraktıkları kültürlerin çoğunlukla kurtulmaya çalıştıkları 'istenmeyenler'dir. Ancak yine geride bıraktıkları kültürde istenmemekle birlikte sadece karanlık ortaçă̆ Avrupa'sının dinimezhepsel ötekisi oldukları için hicret edenler de bulunmaktadır.

Amerika Birleşik Devletleri tarihinde kilise-devlet ilişkilerinin şekillenmesi, kurucu topluluklar olarak başta Avrupa olmak üzere öteki dünyadan gelen muhacirlerin toplumsal tecrübesinden bağımsız olarak gerçekleşmemiştir. Amerika'ya Avrupa'nın dini ötekileri olduğu için gelip sosyal çekirdeği oluşturan Protestan topluluklar, inanç özgürlüklerini elde edecekleri bir ülkeyi düşleyerek uzun bir yolculuğa katlanmışlardır. Ancak yeni dünyaya dinsel baskıdan kaçarak gelen topluluklar, başta kolonyal dönem olmak üzere ülkelerinde

\footnotetext{
${ }^{2}$ Sevinç Alkan Özcan, Rusya ve Polonya'da Din, Kimlik, Siyaset, (İstanbul: Küre Yayınları, 2012), 32.

${ }^{3}$ Alkan Özcan, Rusya ve Polonya'da Din, Kimlik, Siyaset, 53-54.
} 
yaşadıklarına benzer yoğun dinsel çatışmalara şahitlik etmişlerdir. Buradaki çatışmalar, geldikleri yerlerden daha az kanlı sonuçlar doğurmuş olsa da edindikleri tecrübeler, ülkenin özellikle inanç özgürlüğü temelinde kurgulandığı yolundaki Amerikan söylemini boşa çıaracak kadar güçlüdür. Dini düşünce, Amerikan tarihine yön veren başat unsurlardan birisidir. Başını Protestanlığın çektiği çoklu dini yapı, kolonizasyonun ilk zamanlarından başlayarak Amerikan sosyal ve siyasi hayatında belirgin bir hâkimiyet kazanmıştır. İngiltere'den bağımsızlıklarını elde edinceye kadar bağımsız koloniler şeklinde mevcudiyetlerini devam ettiren topluluklar, din olgusunu daima sosyal yaşantılarının merkezinde konumlandırmışlardır. Bütün kolonilerde din ve devlet ilişkisinin farklı uygulandığı bu yapıda, başta Protestan gruplar olmak üzere farklı dinî toplulukların dâhil olduğu bir yelpaze söz konusudur. Bu farklılık eş zamanlı olarak, devletin dini yapılarla ilişkilerinde izlenmesi gereken yol konusunda renkli bir tartışma ortamına vesile olmuştur. ${ }^{4}$

Federatif bir yapıda birleşmenin zorunlu bir ihtiyaç olduğunu düşünen koloniler, bağımsızlık sonrası Amerika Birleşik Devletleri'ni kurarak 1787'de yürürlüğe giren anayasayla devletin siyasî iskeletini oluşturmuşlardır. Ancak kolonilerin farklı itirazlarına rağmen kabul edilen anayasanın, devletin dini yapılarla ilişkileri hususunda herhangi bir çözüm getirdiğini söylemek mümkün değildir. Bundan dört yıl sonra 1791'de hayata geçirilen Haklar Bildirisi, din-devlet ilişkilerine ortak bir çözüm getirmek ve anayasanın sivil haklar açısından desteklenmesi kaygılarını taşır. Haklar Bildirisi'nin birinci maddesi, söz konusu ilişkilerin düzenlenmesi maksadıyla kaleme alınmıştır. "İlk Tadil” (The First Amendment) şeklinde adlandırılan bu madde, kabul edildiği tarihten beri devletin dini yapılar nezdindeki durumunu ve kilise ile devlet kurumunun mesafesini düzenleyen temel başvuru noktası olmuştur. ${ }^{5}$

Müreffeh ve muktedir bir gelecekle birlikte emperyal hayallere sahip bir devlet olarak Amerika, siyasi teorik ve pratikleri açısından köklerinin bir kısmını teslim aldığı Avrupa'dan kıyas götürmez biçimde fakir bir içeriğe sahiptir. Tekemmül etmiş siyasi yapısını çeşitli sancılı evreleriyle Hıristiyan teoloji, Rönesans, Reform ve aydınlanma fikriyle birlikte kadim kültürel gelenekler ve idari tecrübeleri birleştirmek suretiyle oluşturan Avrupa, görece emekleme döneminde bir devlet sayılabilecek olan Amerika'dan büyük farkla ileridedir. Karşılı̆̆ında bağımsızlık sonrası Amerikalıların ellerinde sadece kurucu babaların teorik birikimi ve Püritenlerin yeni kıtaya getirdikleri dini miras bulunmaktadır. Amerikalı yöneticiler, özellikle büyük bölümü teorik ve pratik birikimden oluşan eksikliği gidermek için dine başvurma yolunu seçmişlerdir. Tocqueville, 1850 tarihinde yazdığı “Amerika' da Demokrasi" ismindeki eserinde, Amerikalıların demokrasi inşasında özellikle dini gruplara

\footnotetext{
${ }^{4}$ Orçun İmga, Amerika'da Din ve Devlet Tarihî ve Felsefî Temeller, (Ankara: Liberte Yayınları, 2010), 21-22.

${ }^{5}$ İmga, Amerika'da Din ve Devlet Tarihî ve Felsefî Temeller, 22.
} 
farklı bir önem ve öncelik verdiğinin altını çizer. 19. yüzyılın ikinci yarısına kadar söz konusu inşa ile birlikte siyasi-kamusal yapının teşekkülünde, nüfusun büyük çoğunluğunu oluşturan Püritenlerin faaliyetleri ve püriten öğreti özel bir önemi haizdir. ${ }^{6}$

Özellikle erken dönem yönetici elit, Amerika ve Amerikalıların kutsal bir göreve sahip olduğunu iddia ederek sürekli tekrarlamışlardır. Püriten öğretinin ana dinamiklerinden biri olan 'seçilmiş insanlar' metaforu, Amerika'ya bireysel kaygılarla göç edilen bir toprak parçasının ötesinde kutsal bir anlam yüklemiş, "Yeni İsrail", diğer bir ifadeyle vaat edilmiş topraklar olarak algılanmıştır. Püritenler, "Yeni İsrail" yönünde gerçekleştirdikleri göç dalgasını "Çöldeki Hizmet” olarak görmüşler, yeni vatanı da "Tepede Parlayan Bir Şehir" olarak telakki etmişlerdir Amerikan yöneticileri, ilk zamanlardan itibaren Amerika'nın kutsal bir görevle donatıldığına inanmış ve bu inançlarını sürekli olarak dile getirmişlerdir. Yöneticilerin Amerika hakkındaki bu kutsal görev düşüncesinin en önemli sembollerinden birisi de hiç kuşkusuz New York'ta yükselen Özgürlük Anıtı olmuştur.7

Kavramı Rousseau'dan ödünç alan Bellah'a göre sivil din, bir ülkede geleneksel dini yapı tarafından da desteklenerek toplumsal bütünleşmeyi sağlayan ortak sembol ve ritüellere verilen isimdir. Nihai gerçekleri ve potansiyel toplumsal bölücülüğü ile din, ulusdevletin en eski sorunudur. Bu durumda tüm yurttaşlar için bir yarı-din yaratmaktan daha iyi bir fikir olamaz. Bellah'ın makalesi, en modern ulus-devletlerde bile milliyetçiliğin dinin kabuğuna nasıl büründüğünü gösteren en iyi kaynaktır. ${ }^{8}$

Bellah, 'kendi ciddiyet ve bütünlügüne' sahip olduğundan Amerikan sivil dininin resmi Hıristiyanlıktan farkı olduğunu söyler. Hıristiyanlık ve sivil din arasındaki çekişme bir yana, Amerikan kültürünün sembol, inanç ve ritüelleri, ülke tarihindeki sosyal krizler ve kırılma noktalarına işaret eden cevaplar şeklinde oluşup gelişmişlerdir. Söz konusu dönemler, öncelikle devrim, Amerikan iç savaşı ve başta Vietnam olmak üzere yirminci yüzyılda dünyanın farklı coğrafyalarında girilen küresel etkinlik çatışmalarıdır. Bununla birlikte sivil din, Lincoln ve John F. Kennedy'nin ölümlerindeki kutsallık, şehitlik ve restorasyon söylemleriyle de doludur. Amerikan Anayasası, Bağımsızlık Bildirgesi ve Gettysburg söylevi sivil dinin kutsal yazılarıdır. Her ne kadar bütün görüngüleriyle sivil din fikri, Amerikan milli birlik düşüncesini pekiştirme amacını taşıyor olsa da son dönemlerde Amerikan toplumsal yapısının hizla "kaygisız toplum" olma yoluna girdiği

\footnotetext{
${ }^{6}$ Ömer Çaha, Bitmeyen Beraberlik Modern Dünyada Din ve Devlet, (İstanbul: Timaş Yayınları, 2008), 142-143.

${ }^{7}$ Çaha, Bitmeyen Beraberlik Modern Dünyada Din ve Devlet, 95.

${ }^{8}$ Gerd Bauman, Çokkültürlülük Bilmecesi, Ulusal, Etnik ve Dinsel Kimlikleri Yeniden Düşünmek, trc. Iş11 Demirakın (Ankara: Dost Kitabevi Yayınları, 2006), 46.
} 
vurgulanmaktadır. ${ }^{9}$ Tüm seküler görüntüsüne ve kurumsal dini yapılarla devletin ilişkilerinde hayata geçirilen yasal düzenlemelere rağmen Amerikan devlet anlayışında dini düşünce, en az toplumsal yapısında olduğu kadar etkin ve belirleyici aktör konumundadır. Ülkede vatandaşların yönetime aktif siyasal katılımları, önemli oranda dini güdüleyicilerle oluşturularak yönlendirilen sivil toplum örgütleri ya da yeterince siyasallaşmış ve siyaset üzerinde tırmanan bir etkiye sahip kilise cemaatleri vasıtasıyla olmaktadır. Başta Evanjelikler, Protestanlar, Katolik cemaatler ve arkasından Yahudiler olmak üzere Amerikan sosyal hayatında varlık ve faaliyet gösteren dini gruplar, enerjilerinin önemli bir kısmını siyasi yelpazede güç ve etkinliklerini artırmak üzerine yoğunlaştırmışlardır.

2014 yılına ait bir araştırmaya göre, Amerikan siyasetindeki ikinci önemli dini grup olan Katolikler, nüfusun \% 20.8'ni oluşturmaktadır. Aynı araştırmaya göre, Amerikan nüfusunun sadece \% 1.9'unu oluşturan Yahudiler, sayılarına ters orantılı olacak bir biçimde Amerika'daki en etkili üçüncü dini grubu oluşturmaktadır. Aynı birimin 2012 yılına ait bir araştırmasına göre, Amerika'da 1970 yılında kırk tane dini lobi grubu bulunurken, bu sayı 2010 yılında iki yüzü aşmıştır. Amerikan siyasi hayatında dini grup lobilerinin etkinliğini, söz konusu artışın hem sebebi hem de doğal bir sonucu olarak kabul etmek mümkündür. ${ }^{10}$

Anderson ve Bellah bizleri devletin dünyevi gereksinimleri karşllayan seküler bir alandan ibaret olduğuna dair naif yaklaşımdan oldukça uzaklaştırmışlardır. Ulus-devlet seküler-ci olmaya çalışır, ancak kendisi hiçbir şekilde seküler değildir. Yani kiliseleri ve ibadeti özel alana iter, ancak gizemli retorik ve ritüelin ardında bıraktığı boşluk, hızla devlet yapımı bir dinle dolar. Tüm devletlerin ulusları, üstün ahlaki bir süperetnos buyruk varmışçasına oluşmuş hayali topluluklar olarak inşa edilmiştir ve ulus-devlet, dinsel olanlarından hiç de geri kalmayan bir simgesel değerler, yerler ve tarihler ağına dayanır. ${ }^{11}$ Kutsallaştırılan bir devlet formu olarak sivil din ile birlikte dini grupların devlet ve siyaset üzerindeki etkileri göz önüne alındığında, ABD'de dini kurumlarla devletin son derece yoğun ve karmaşık bir ilişkiler ağına sahip olduğunu söylemek mümkündür.

\section{AVRUPA’DA DEVLET AKLI: LAİK GÖRÜNÜMLÜ DİN SIMMSARLIĞI}

Kuşkusuz, ruhanî ve dünyevî alanlar arasındaki egemenlik mücadelesi, en yoğun biçimde Hıristiyanlığın yayılım coğrafyasında hissedilmiştir. Dünyevi iktidara dini meşruiyet sağlama amacına dönük bu çatışmalar, özellikle Avrupa' da uzun soluklu ve yıkıcı savaşlara gerekçe oluşturmuştur. M.S. 60 tarihinde St. Paul'ün dini tebliğ için Roma'ya gelişi,

\footnotetext{
${ }^{9}$ Yasin Aktay, “Amerika'da Din Devlet İlişkileri ve Dini Cemaatlerin Etkisi”, Devlet ve Din İlişkileri Farklı Modeller, Konseptler ve Tecrübeler (Ankara: Konrad Adenauer Vakfi Yayını, 2003) 38-39.

${ }^{10}$ Onur Yıldırım, “Amerika'da Dinin Siyaset Üzerindeki Etkisi”, Ekonomi İşletme Siyaset ve Uluslararası Ilişskiler Dergisi JEBPIR 1/2 (2015): 101-102.

${ }^{11}$ Bauman, Çokkültürlülük Bilmecesi, Ulusal, Etnik ve Dinsel Kimlikleri Yeniden Düşünmek, 48.
} 
Hıristiyanlığın nevi şahsına münhasır özelliklerinden hayat bulan çatışmanın başlangıç noktası olarak kabul edilebilir. Hiristiyanlık, müntesiplerine uzun yıllar boyunca uygulanan kurumsal baskılardan sonra kitlesel katılımlarla büyüyerek göz ardı edilemeyecek bir gücün sahibi olmuş, bu sayede, "devlet dini" şeklinde kabul görmesinin yolunu da açmıştır. Devlet tarafından kabul gören dinin siyaseten güçlenmesi, kendi hiyerarşisi ve normatif yapısı ile kurumsal bir yapı olarak kiliseyi ortaya çıkarmıştır. Kilise, kısa zamanda dünyevi iktidara ortaklık talepleri olan, toplumsal kanaat oluşturma erkine sahip, çok büyük bir ekonomiyi yöneten ve kamunun her alanında söz sahibi bir güç odağ haline gelmiştir. Kurumsal dinin temsilcileri olarak ruhban sınıfı, bütün toplum üzerinde önemli yasal yetkilerle donatılmış ayrıcalıklı bir grup hâline gelir. Diğer taraftan Ortaçağ sonlanırken burjuva sınıfının önem ve etkinliğinin artışı, kilisenin sahip olduğu kurumsal güce sekte vurur. Reform hareketi ve Kalvinizm'le birlikte yeni güçlü sınıfın, sadece feodal elitlere değil aynı zamanda ruhban sınıfına karşı da verdiği güçlü mücadele, kurumsal dine ve kiliseye çok büyük kan kaybettirir. Avrupa'da 1648 tarihinde yapılan Westphalia Barış Antlaşması'na kadar devam eden din kökenli çatışmalar, kapitalist düşüncenin doğuşu, Rönesans ile yaşanan sosyal kırılma ve bilimsel ilerleme, kilisenin daha zor duruma düşmesini sağlayan Fransız Devrimi'nin habercisi gibidir. Avrupa'da kurumsal din ve devlet arasındaki düzensiz ilişki, söz konusu dönemden itibaren ayrılma yönünde belirginlik kazanmaya başlamıştır. ${ }^{12}$

Bazı kiliselerin kendi ruhbanlarını seçerek daha özerk hale gelme talepleriyle ayrılmaları, Avrupa'da kurumsal dinin en yüksek temsilcisi olan Vatikan'ın kan kaybetmesine sebep olmuştur. Bununla birlikte Vatikan'a karşı geliştirilen Protestan reddiye, dünyevi iktidarın kutsal hakları ve benzeri konularda mevcut toplumsal şüpheyi tetiklemiştir. Bütün gelişmelerle birlikte Katolik Fransa ile Protestan İngiltere örneğinde olduğu gibi Reform hareketinin can suyunu verdiği savaşlar, çeşitli kültürel ayrılıkların hızla ulusal bilince tahvil edilmek suretiyle siyasi kümeleşmelere dönüşmesine yol açmıştır. ${ }^{13}$

Bireyin keşfedildiği ve aklın en hızlı yükselişine sahne olan Avrupa'da devletin din konusunda geliştirdiği genel bakış açısı, bir ülkeden diğerine sadece küçük ton farklılıklarını içerir. Avrupa'da devlet, bütün çatışmalı geçmişine rağmen göründüğünden çok daha dindardır. Çünkü ulus devlet anlayışı, din kurumunu doğum yeri olan Avrupa'da en az dünyanın geri kalanında olduğu kadar önemli bir ulus-altı bileşen olarak tanımlar. Aklın dine galebe çaldığı coğrafya, aynı zamanda çok uzun soluklu din-devlet çatışmasının merkezi ve tükenmek bilmeyen mezhep ya da din savaşlarında öldürülenlere şahitlik etmiş bir tarihin sahnesidir.

\footnotetext{
${ }^{12}$ İmga, Amerika'da Din ve Devlet Tarihî ve Felsefî Temeller, 19-21.

${ }^{13}$ Craig Calhoun, Milliyetçilik, trc. Bilgen Sütçüoğlu (İstanbul: Bilgi Üniversitesi Yayınları, 2012), 100.
} 
Akıl ve modern değerlerin doğum yeri sıfatını kullanan bugünün Avrupa'sında, devlet gözlüklerinin arkasına gizlenmiş dini düşüncenin etkilerini ilk bakışta görmek mümkündür. Sadece toplumsal düzenin çatı yapısı olan anayasal metinlere yöneltilecek hızlı bir bakış bile kutsalın devletini görmek için yeterli olacaktır.

Alman Anayasası'nda "Tanrının yardımını isteyen" Cumhurbaşkanı yemin metninden, Bulgaristan'da geleneksel din olarak Doğu Ortodoks Hiristiyanlığının belirlenmesine, Danimarka ve Norveç'te kralın resmi din olan Evanjelik Luteryen Protestanlığa mensup olma zorunluluğundan, Finlandiya'da resmi devlet dinlerine ait yasalara kadar temel düzenlemeler kutsanmıştır. Kilisenin kutsal tınılarını, İngiltere'de Anglikan ve Presbiteryen, Fransa'da Katolik kiliselerinin imtiyazlarını güvence altına alan yasal metinlerde duymak mümkündür. ${ }^{14}$

Yunanistan'ın resmi ve egemen kilisesi olan Doğu Ortodoks Kilisesi devletin geri kalanından farklı olarak sadece kendisine ait 1977 Anayasası kurallarıla yönetilmektedir. Bu durum, ülkede din ve devlet ilişkisindeki güven seviyesinin de göstergesidir. Hâlihazırda din işleri ve milli eğitimi de yürüten bir devlet bakanlığı gücündeki kilise, toplumsal iş ve faaliyetlerin çoğunda devletin temel paydaşı konumundadır. Yunanistan'da Doğu Ortodoks inancının dışındaki inançların serbestçe ifadesi ya da rekabeti söz konusu olmak bir tarafa yasal olarak cezaya tabidir. Kimliklerde dinin belirtilmesi konusundaki yasal zorunluluk, devletin uluslararası arenada karşılaştı̆̆ı sorunların başında gelmektedir. ${ }^{15}$

Bünyelerindeki canlı dini kimlikleri, anayasal metinleri, dile getirilmese de rengini Meryem Ana'nın mavi pelerininden ve yıldızlarının sayısını on iki havariden alan bayrağıyla, Avrupa Birliği gibi siyasi-ekonomik bir tümleşik yapıyı oluşturmak maksadıyla kullanılan temel etkenin "din" olduğunu söylemek hatalı bir tespit olmayacaktır. ${ }^{16}$ Ancak hemen burada ister istemez akıllara "hangi din" sorusu gelmektedir. Hıristiyanlığın, her biri farklı birer din haline gelmiş, bunun da ötesinde farklılıkları sayesinde Avrupalı milli kimliklerin temel belirleyicisi olmuş mezhepleri, ortak bir Avrupalı kimliği oluşturmak için ne kadar elverişlidir? Tarihi tecrübeyle de sabit olduğu üzere birbirlerine kıyasla iç öteki nitelemesini hak eden farklı Avrupalı milli kimliklerin, müşterek bir yurttaşlık zemininde kolayca buluşabilecekleri, ya da dış öteki İslam toplumlarıyla olduğundan daha az sorun yaşayacakları konusunda ne kadar iyimser olunabilir? Kanımızca Hıristiyanlık, her ne kadar yaklaşık üç çeyrek yüzyıldır inşası için uğraşılan kapsayıcı bir Avrupalı kimliğinin temel

\footnotetext{
${ }^{14}$ Hüdai Şencan, "Bazı Avrupa Ülkelerinde Din ve Devlet İlişkisi Raporu”, (TBMM Araştırma Merkezi, 2011), 10-79. https://anayasa.tbmm.gov.tr/docs/bazi_avrupa_devletlerinde_din_ve_devlet_iliskileri.pdf

${ }^{15}$ Mehmet Kahraman, “Avrupa Birliği Ülkelerinde ve Türkiye'de Laiklik”, Mustafa Kemal Üniversitesi Sosyal Bilimler Enstitüsü Dergisi 5/9 (2008): 63.

${ }^{16}$ Muhittin Imıl, Ulus İnşa Sürecinde PKK ve Din İlişkisi (Doktora Tezi, Süleyman Demirel Üniversitesi, 2016), 48.
} 
tutunum noktası olarak belirlenmiş olsa da aynı zamanda ortak vatan, bayrak ve kimlik temelinde birleşememenin temel sebebidir. Hıristiyanlık, bu bakış açısıyla Avrupalı kimliğinin içinden çıkılması müşkül dilemmasıdır. Bütün ortak kurumlarına rağmen ortak bir güvenlik yapılanması ve silahlı güç oluşturmak bir yana milli hukuklarından bile $\mathrm{AB}$ ortak hukuku lehine çekilmeye yanaşmayan üye devletler, bu ikilemi göz göre göre yaşamaya devam edeceklerdir. Yukarıda çok kısa bahsedilen milli mezhepler ve kiliseler konusundaki anayasal ve yasal düzenlemelerden vazgeçmedikleri sürece istenen birlikteliği kâğıt üzerinde bile inşa etmek mümkün görünmemektedir. Üye devletler, milli kiliselerden feragat eder ve bu alandaki yasal düzenlemeleri adil biçimde yeniden ele alırlarsa, varlık gerekçelerini bir ütopya uğruna kaybedeceklerini düşünerek yeterince istekli davranmayacaklardır. Belki de Avrupa toplumlarının tarihsel bagajlarında taşıdıkları sosyal hassasiyetleri yeterince göz önüne almadan tamamen pragmatik bir yaklaşımla ve bürokratik elitin zorlamasıyla ortaya çıkacak prematüre bir yapı, bahse konu bagajların istemsizce açlarak ortaya dökülmesine, kanlı Avrupa tarihinin tekerrür etmesine vesile olacaktır.

\section{DİN-DEVLET İLIŞKİSINDE BOLŞEVİK FAYDACILIK: SOVYET RUSYA ÖRNEĞİ}

Ulusçuluk, Ortodoks ülkelerde kilise ve devlet ilişkilerini anlamak için en başta ele alınması gereken temadır. Zira Ortodoks kiliseler aynı zamanda ulusçuluk ideolojisinin en canlı biçimde ortaya çıktığı kurumlardır. 19'uncu yy. sonlarında Bulgaristan ve Sırbistan'da ulusal patrikliklerin kurulmasıyla birlikte ulusal kimliğin otantikleştirilmesi rolünü üstlenen Bulgar ve Sırp kiliseleri ulus-devlet inşasının önemli unsurları olarak ortaya çıkmıştır. Rus Ortodoks kilisesi ise her siyasi atmosferde kendisini Rus kimliğinin ayrılmaz bir parçası olarak tanımlar. 1920'li yıllarda Ukrayna Otosefal Kilisesi'nin Ukraynalılaştırma politikalarına Balkanlar'daki Ortodoks kiliselerine benzer bir biçimde destek vermesi, ulusçuluk bağlamında verilebilecek önemli örneklerden biridir. Bolşevizm öncesi Rusya'da Ortodoks kilisesinin Polonya, Belarus ve Ukrayna halklarının Ruslaştırılmasında bir araç olarak kullanılması herkesçe bilinen bir olgudur. Benzeri bir biçimde Bulgar Kilisesinin Makedonya ve Arnavutluk'un bazı bölgelerinde kurduğu okullar Bulgarlaştırma politikalarına hizmet ederken, Yunan Ortodoks kilisesi Yunan ulusçularının Kuzey Epir olarak adlandırdıkları bölgede yaşayan Arnavutlar arasında Yunan dil ve ulusal kimliğinin yayılmasında önemli roller oynamıştır. Bağımsızlığını kazandığı 1912 yılına kadar Arnavutluk'ta Ortodoks din hizmetlerinde Yunan dilinin kullanılması ve Ortodoksların 
Yunan olarak adlandırılması, dinin ulusal kimliğin emperyal bir biçimde yayılmasına nasıl hizmet ettiğini gösteren ilginç bir örnektir. ${ }^{17}$

Sovyet Rusya'da milli kimlik inşası çabaları, gözlemlemeye değer bir örnek teşkil eder. SSCB, Bolşevik İhtilali'nden itibaren sosyalist düşüncenin dünyaya ihracını kendisine ideolojik hedef olarak belirlemiştir. Bu hedef doğrultusunda, 1930'lu yılların sonuna kadar tüm dinler ve daha sonraları Müslüman toplumda, sosyalist idealleri gerçekleştirmek için çalışan 'Sovietsky Çelovek' (Sovyet İnsanı) oluşturulmak istenmiştir. Bunun için öncelikle bireyin dini duygulardan uzaklaştırılması gerekmektedir. ${ }^{18}$ Bunun imkânsızlığını gören Sovyet yöneticiler, dinsizleştirme politikasını terk ederek Ortodoks inancını Sovietsky Çelovek'in tek kutsal bileşeni haline getirmeye çalışmıştır. Sovyet coğrafyasında Ortodoks Hıristiyanlığın dışındaki en güçlü din olan İslam, Türkistan'daki toplumsal ve ekonomik yapıyı şekillendirme gücüyle rejime alternatif oluşturabileceğinden, Sovyet devlet aklının en fazla saldırdığı ve sosyal etkilerini yok etmeye çalıştı̆̆ı dini yapı olmuştur.

Ruslaştırma politikalarıyla öncelikle Ortodoks Hıristiyanlık milli kimliğin temel bileşeni haline getirilmeye çalışılır. Diğer yandan Müslüman Türkler arasında mikro milliyetçilikler kaşınarak, kendi aralarında yabancılaştırmak, Müslümanlı̆̆ı toplumsal bilinçten silmek ve Pantürkist/Panislamist hareketler engellenmek istenmiştir. Roy'a göre, Rusya Müslümanlarının milli hareketi denince akla gelmesi gereken şey, modern anlamıyla bir milliyetçi hareket yerine, dinsel ve kültürel kıstaslara dayanan bir Müslüman Milleti hareketidir. Reformculara göre Rusya Müslümanlarında, Türk diline dayalı bir Pantürkizm'le karışık Panislamizm söz konusudur. ${ }^{19}$

Sovyet Rusya'da yönetim, sosyal hayattaki etkinliğiyle İslam dininin, milli azınlıkların temel belirleyici unsurlarından birini oluşturduğunun ayırdındadır. İlk başlarda Sovyet rejimi bu doğrultuda, temel İslami kuralları ortadan kaldırma ve aynı zamanda söz konusu esasların uygulanmasını engellemeye dönük yoğun bir çalışma başlatmıştır. 19181939 yılları arasında Ortodoks kilisesi ve din görevlilerini de olumsuz etkileyen Bolşevik devrimiyle sayıları on binlerle ifade edilen camiler yerle bir edilirken çok sayıda din görevlisi de öldürülmüştür. ${ }^{20}$ Ülke genelinde, 1917 yılından önce tahminen 26.000 civarında cami varken, bu rakam 1942' de 1312'ye, 1980'lerde ise 400 civarına düşmüştür. ${ }^{21}$

\footnotetext{
${ }^{17}$ Alkan Özcan, Rusya ve Polonya'da Din, Kimlik, Siyaset, 163-164.

${ }^{18}$ Seyfettin Erşahin, Türkistan'da İslam ve Müslümanlar (Ankara: İlahiyat Vakfı Yayınları, 1999), 142.

${ }^{19}$ Olivier Roy, Yeni Orta Asya Ya da Ulusların İmal Edilişi, trc. Mehmet Moralı (İstanbul: Metis Yayınları, 2009), 71-72.

${ }^{20}$ Şir Muhammed Dualı, "Rusya Federasyonu'nda Din Eğitimi Meselesi”, Avrasya Incelemeleri Dergisi (AVID) II/I (2013): 225.

${ }^{21}$ Fatma Tombak, “20. Yüzyıl Sovyet Rusya’sında Din, İslamiyet ve Nüfus Üzerine Bir Değerlendirme”, History Studies 3/2 (2011): 363.
} 
Çarlık Rusya'sında, çok küçük farklarla ayrışan etnik kimlikler, Pantürkizm ve Panislamizm sentezine ve Osmanlı tehlikesine karşı desteklenmiştir. Sınırların dışından gelen kontrolü güç bir sorun yerine, içeride bir etnik kimlikle baş etmek daha kolaydır. Miras olarak aldıkları bu siyasi tavrı geliştiren Sovyet yöneticiler, en büyük düşman olarak gördükleri Pantürkizm ve Panislamizm'e karşı, hükümranlıkları altındaki Türk toplulukların bir araya gelmelerini engellemek amacıyla etnik, filolojik, dini tüm farklılıkları körükleyerek çeşitli kimlik inşalarına girişmişlerdir. Roy'a göre, bu yeniden inşa faaliyeti teleolojik bir nitelik taşır: Sovyet yönetiminin sadece etnik kimlikleri değil aynı zamanda dilleri de icat ettiği söz konusu kimlik inşasında, hâlihazırda canlılığını koruyan küçük farklılıklar tarihin şahitliğine başvurarak açıklanır. ${ }^{22}$

Bolşevik etnikleştirmesine güzel bir örnek teşkil eden Azeri kavramı 1920'den sonra ortaya çıkmıştır. O zamana kadar Azerbaycan tamamen coğrafi bir mefhumdur. 1924'ten önce Ruslar Azeri ve Tatarları “Türk" veya “Müslüman” olarak adlandırmışlardır. Azerbaycan'ın reformcu önderleri 1914'ten önce Türk ve Müslüman kimliklerini vurgularlar. ${ }^{23} 1920$ 'den önce bir Azeri kimliğinden söz etmek mümkün değildir. Rus yönetimi, Azerbaycan'da kısa süre için -1850'li yıllarda Vorontsov'un ve 1896'dan 1905'e kadar Golitsin'in valilikleri sırasında- halkın Türkiye ve İran'la milli ve dini bağlarını gevşetebilmek amacıyla, bir Azeri kimliğinin geliştirilmesi konusuna destek sağlamışlardır. Dil ve toprak yakınlığından dolayı sıkı sıkıya yerleşmiş Türk taraftarlığını ortadan kaldırmak için kendine özgü bir Azeri kimliği geliştirmek daha akla yatkındır. ${ }^{24}$

1917-1939 tarihleri arasında kısa süreliğine değişse de, Çarlık Rusya'sından itibaren Rus milli kimlik inşacıları, Ortodoks Hıristiyanlığı sürekli ön planda tutmuşlardır. Devletin özellikle sınır bölgelerinde uyguladığı Ruslaştırma politikalarının merkezinde yer alan kurumlardan biri Rus Ortodoks Kilisesi'dir. Rus olmayanlar üzerinde uygulanan bu kültürel ve siyasi asimilasyon politikası, Rusya'nın modernleşme ve uluslaşma tecrübesinin önemli bir ayağını oluşturur. ${ }^{25}$ Ortodoks Hıristiyanlık, nüfusun yaklaşık \% 80'i için önemli bir kültür unsuru olarak yaşamaya devam etmesi ve Rus tarihinde işgal ettiği merkezi konum sayesinde siyasetçiler tarafından kimliğe ilişkin ana unsurlardan birisi olarak görülmektedir. Rus Milli kimliğinin kültürel temelini oluşturmak üzere kullanılan Ortodoksluğun yaygınlaştırılması politikası, Rus Ortodoks Kilisesi'ni devrim öncesi konumuna getirmiştir. Bugünkü Rusya'da kilise yüzyıllar boyu olduğu gibi baskın bir dini kuruluş, Ortodoksluk ise devlet dini haline gelmiştir. Eski Sovyet Cumhuriyetlerinde olduğu gibi günümüzde de

\footnotetext{
${ }^{22}$ Roy, Yeni Orta Asya Ya da Ulusların Imal Edilişi, 103.

${ }^{23}$ Zbigniew Brzezinski, Büyük Çöküş, trc. Gül Keskil-Gülsev Pakkan (Ankara: Türkiye İş Bankası Kültür Yayınlar1, 1997): 49.

${ }^{24}$ Brzezinski, Büyük Çöküş, 94-95.

${ }^{25}$ Alkan Özcan, Rusya ve Polonya'da Din, Kimlik, Siyaset, 18-19.
} 
devlet, geleneksel inancı milli kimliğin bir parçası haline getirmeye çalışmaktadır. Sovyet sonrası dönemde Rus Ortodoks kilisesi, milli kimliğin yeniden inşası ve eski Sovyet coğrafyasında birleştirici unsur görevini üstlenmiştir. ${ }^{26}$

\section{CUMHURIYYT TÜRKİYE'SINDE DINN KURUMU VE İKTIDDAR TALEPLERİ}

“Bă̆gllıkla inanıp mutlu olduğumuz İslam dinini, yüzyıllardan beri alışılageldiği şekilde bir "siyaset aracı" makamından kurtarmak ve ayırmanın elzem olduğu gerçeğini görüyoruz. Kutsal ve ilahî olan inanç ve vicdanlarımızı, belirsiz ve değişken olan siyasetten ve siyasetin bütün unsurlarından bir an önce ve kesinlikle kurtarmak, milletin dünyevi ve uhrevi mutluluğunun emrettiği bir zorunluluktur. İslam dininin anlamı, ancak bu şekilde ortaya çıkar."

Gazi Mustafa Kemal Atatürk

(1 Mart 1924-Meclis Aç1lış Konuşması)

İnsanlık tarihinin kadim hafızası, din ve devlet ilişkisinde ittifakları olduğu kadar ihtilafları da son derece canlı biçimde hatırlayacaktır. Tanrısal vahyi ileten her peygamberin karşısında muhakkak dönemin muktedirleri vardır. Zaten kutsal söz de bahse konu muktedirlere rağmen toplumsal patolojiye ve iktidara karşı söylenmektedir. Kurulu düzen ya da düzensizliğe sıra dışı bir başkaldırı olarak ortaya çıkan peygamber, sadece din kurucu değil ama aynı zamanda düzen kurucu bir karizmadır. Zamanın çok ilerisindeki peygamber, tüm çağdaşlarına göre statükoya karşı çıkan bir devrimcidir. Oysa peygamberin vefatından sonra güçlenerek kurumsallaşan dini bilginin koruyucu ve tekrarlayıcıları olan din adamları, zaman içinde kendilerinin oluşturduğu statükonun da koruyucusu haline gelirler. Zira artık ilk zamanlarındaki gibi muktedirlere karşı son derece zayıf olan bir dinin inananı değillerdir. Ellerindeki gücün korunması için kendi normatif sınırlarını çizerek köklere sarılmak zorunda olduklarından daha tutucudurlar. Kurumsallaşan din ve devletin, sosyal hayatını düzenlemeye talip oldukları hedef kitle örtüşür. İslam tarihi için de benzer bir geçmişi okumak mümkündür. İslam, müntesipleri ve coğrafyasını genişlettikçe elinde bulundurduğu yönetsel güç başları döndürmüş, kimi zaman devlet dini araçsallaştırarak gücüne talip olmuş, kimi zaman da din toplum nezdindeki etkisiyle özdeş biçimde devlet üzerindeki etkinliğini arttırmıştır. Söz konusu güç mücadelesinin benzer tezahürleri Türkİslam tarihi için de geçerlidir.

\footnotetext{
${ }^{26}$ Anar Somuncuoğlu, “Rus Ortodoks Kilisesi’nin Eski Sovyet Alanındaki Misyonu”, Karadeniz Araştırmaları Dergisi 2 (Yaz 2004): 93-107.
} 
Türk-İslam tarihinde din ve devlet ilişkisindeki değişimi anlamak için Şeyhülislamlık kurumunu incelemek zaruridir. X. yüzyılda bir saygı ifadesi olarak ortaya çıkan Şeyhülislam kavramı, önce Horasan Şafiileri, sonra Memlukler'de unvana dönüşmüş, Safevi İran'da resmi bir mahiyet kazanmış ve nihayetinde Osmanlı İmparatorluğu'nda kurumsallaşmasını tamamlamıştır. Kazaskerlik ve Bursa kadılığı mevcutken $1425^{\prime}$ te ayrıca dinî-hukukî bir makam olarak Şeyhülislâmlığın ortaya çıkışında, dönemin sosyal dinî ve siyasî durumunun etkisi vardır. Hemen Fetret devri sonrası yaraların sarılmaya çalışıldığı, birtakım Rafızi hareketler ve diğer bazı önemli gelişmelerin yaşandığı hassas bir dönemde siyasî iktidarın dışında dinsel itibar kazandırılan ilmi bir makamın ortaya çıkışı, ayrıca önemlidir. XVI. yüzyıl başlarında Zenbilli Ali Efendi'nin II. Bayezid ve Yavuz Sultan Selim devrindeki yirmi üç yıllık (1503-1526) Şeyhülislâmlık dönemi, kurumun padişahı hem dini hem de dünyevi kontrol görev ve yetkisini üstlenmesi açısından bir dönüm noktasıdır. XVI. yüzyıl sonlarından itibaren fiilen idarenin içinde bulunarak devletin siyasî kararlarında veziriazamlarla eşit rol üstlenen Şeyhülislamlık, XVII. yüzyılda devletteki değişim ve zaaftan etkilenmiş, veziriazamla şeyhülislâmın yetki çatışması körüklenmiştir. Bu yüzyıldan itibaren şeyhülislâm, önemli ölçüde ulemanın sözcüsü gibi hareket etmeye başlamış, çoğunlukla kendi iradesi dışında Beylerbeyi Olayı (1589), II. Osman Olayı (1622), Patrona İsyanı (1730), Kabakçı İsyanı (1807) gibi olayların örnek verilebileceği askerî ayaklanmalarda, kıyama meşruiyet kazandırmak ve fetvasını almak maksadıyla siyasete dâhil edilmiştir. XVIII. yüzyılda şeyhülislâmların siyasete karışması kuruma daha fazla itibar kaybettirmiş, Vak'a-i Hayriye'den (1826) sonra gücü azalan şeyhülislâm, aynı yüzyıldaki idarî düzenlemelerle kabine üyesi olmuştur. Şeyhülislâmların birinci önceliğe sahip vazifeleri, dini ve siyasi konularda özellikle Hanefî fıkhına göre fetva vermekten ibarettir. Dünyevi iktidarın merkezindeki otoritenin, inancı ve hukuku kendi amacına dönük olarak siyaseten nasıl araçsallaştırdığı konusunda benzersiz örnekler olan söz konusu fetvaların içinde 'hal' fetvaları ayrıcalıklı bir konuma sahiptir. Çoğunlukla siyasi gerekçelerle ve değişen duruma göre asker-ulema iş birliği içinde oluşturulan bu fetvaların doğrulukları şüphelidir. Osmanlı gibi çok dinli ve kültürlü, dünyanın geri kalanıyla önemli temasları olan bir devlet söz konusu olduğunda, devlet siyasetiyle şer'i hukuku bağdaştıran fetvalar devletin devamı açısından zaruri görülmüştür. ${ }^{27}$

Osmanlı'da yenileşme hareketleriyle birlikte gelişen toplumsal gruplar ve Batılı değerlerle yetişen askeri-sivil bürokrasi karşısında, şeyhülislamın başında bulunduğu ilmiye teşkilatı gerilemiş, kamu yönetimindeki bazı görevlerini sivil kurumlara devretmek zorunda kalmıştır. Bu dönemde merkeziyetçi bir dönüşüm geçiren bürokrasideki uzmanlaşma,

\footnotetext{
${ }^{27}$ Mehmet İpşirli, “Şeyhülislâm”, Türkiye Diyanet Vakfi İslam Ansiklopedisi (Ankara: TDV Yayınları, 2010), 39: 91-96.
} 
ilmiyenin görev alanını daraltıp siyasi gücünü azaltmış, bürokrasi tarafından kontrol edilmesine ve dinin etkinliğini azaltarak devletin dünyevileşmesine sebep olmuştur. Nitekim o zamana kadar şeyhülislamlar görevini evinden yürütürken, Yeniçeri Ocağının lağvından (1826) sonra Ağakapısı'na taşınarak kuruma devlet dairesi hüviyeti kazandırılmış, aynı zamanda oluşturulan kabine sisteminde hükümet üyesi sayılarak görev süresi hükümetle sınırlandırılmıştır. 1839'da kurulan Şuray-1 Devlet ile kurumun dâhili siyasetteki etkisi kırılmış, 1879'da Adliye Nezareti'ne bağlı yeni asliye ve ceza mahkemelerinin kurulması, Şer'iye ve Nizamiye Mahkemeleri yetkilerinin kısıtlanması, 1916'da kurulan yeni hükümetle birlikte Şer'iye Mahkemelerinin Adliye Nezareti'ne ve medreselerin Maarif Nezareti'ne bağlanmasıyla yetkileri aşama aşama kısıtlanmıştır. ${ }^{28}$

Şeyhülislâmlığın Osmanlı modernleşme sürecinde iktidar alanının daralması konusunda geçirdiği dönüşüm, Türkiye Cumhuriyeti'nin kuruluşu ile kaldığ yerden devam etmiştir. Gazi Mustafa Kemal Atatürk'ün 1 Mart 1924 tarihinde meclis açılışındaki konuşmasında belirttiği gibi temel amaç, İslam dinini bir "siyaset aracı" olmaktan kurtarmaktır. Bunun için gerektiği düşünülen tüm adımlar atılacaktır. Türkiye Büyük Millet Meclisi'nin açılışından sonraki yeni hükümetin 3 Mayıs 1920'de oluşturulan ilk İcra Vekilleri Heyeti'nde Osmanlı Devleti'ndeki Şeyhülislamlık ve Evkaf Nezareti'nin yetki ve sorumluluklarını yüklenen "Şer'iye ve Evkaf Vekâleti" adı altında bir bakanlık yer almış ve 3 Mart 1924'e kadar Türkiye'de din hizmetleri dört yıl boyunca bakanlık düzeyinde yürütülmüştür. ${ }^{29}$ Cumhuriyetin ilanından üç ay sonra 3 Mart 1924 tarihinde 429 sayılı “Şer'iye ve Evkaf ve Erkan-1 Harbiye-i Umumiye Vekâletlerinin İlgasına Dair Kanun" ile devlet idaresinde geçmişte olduğu kadar değilse de yüksek bir etkinliğe sahip olan "Şer'iye ve Evkaf Vekâleti" kaldırılarak yerine Başbakanlığa bağlı "Diyanet İşleri Reisliği" kurulmuştur. Aynı oturumda 430 sayılı “Tevhid-i Tedrisat Kanunu” kabul edilerek ülkedeki bütün eğitim-öğretim kurumları Milli Eğitim Bakanlığı'na bağlanmıştır. Kanun kapsamında Şer'iye ve Evkaf Vekâleti ya da özel vakıflar tarafından idare olunan bütün medrese ve mektepler Milli Eğitim Bakanlığı'na devredilmiştir. Bununla birlikte dinî hizmetler için İmam ve Hatip Mektepleri ile Darülfünun'da bir İlâhiyat Fakültesi açılması kabul edilmiştir. ${ }^{30}$

Yukarıda sözü edilen ilk kanunla birlikte kurucu irade, din kurumunun kurtuluş mücadelesi esnasında da tecrübe ettiği gücünü kontrol etmek ve sinırlarını belirlemek konusundaki niyetini açıç̧a beyan etmiştir. Kurumsal din, bakanlık seviyesinden

\footnotetext{
${ }^{28}$ Kemaleddin Taş, Türk Halkının Gözüyle Diyanet, (Ankara: İz Yayıncılık, 2002), 92-95.

${ }^{29}$ Kemaleddin Taş, "Osmanlı Yönetim Sisteminde Şeyhülislamlık Kurumu -Sosyolojik Bir Çözümleme-”, Süleyman Demirel Üniversitesi Sosyal Bilimler Dergisi 1/1 (2005): 81-101.

${ }^{30}$ Medine Sevim - Turgay Gündüz, "Türkiye’de Cumhuriyet Dönemi Din Eğitimi ve Öğretimi Kronolojisi”. DEM Dergi 1/2 (2007): 64.
} 
Başbakanlığa bağlı bir başkanlık seviyesine indirilmek suretiyle Osmanlı İmparatorluğu devrinden alışageldiği devlet yönetimi konusundaki tasarruf ve etkinliğini kaybetmiştir. İkinci kanun ise kurumsal dinin sadece devlet değil toplum üzerindeki etkinliğinin de sınırlandırıldığının göstergesidir. Medreseler de dâhil olmak üzere bütün okulların Milli Eğitim Bakanlığı'na devredilmesini, devletin toplumsal hayat üzerinde de son derece etkin ve güçlü olan dini elite karşı bir meydan okuması olarak değerlendirmek mümkündür. Ancak her iki kanun da yürürlüğe girdikleri tarihte düşünülüp bir anda hayata geçirilen türedi düzenlemeler değildir. Söz konusu kanuni düzenlemeler, yukarıda detaylı olarak sözü edilen ve Osmanlı modernleşmesine uzanan köklere sahip olmakla, cumhuriyetten daha kadim bir hafızanın ürünüdür.

Cumhuriyet döneminde kurumsal din konusundaki düzenlemelere dünyadaki diğer laik uygulamalarda görülmeyen bir yöntem olarak devletin dini kontrol etmesi açısından bakmakta yarar vardır. 14 Mayıs 1931 yılında Cumhuriyet Halk Partisi'nin tüzügüne dâhil edilen laiklik, 5 Şubat 1937'de anayasa maddesi haline gelmiştir. 1961 Anayasası'nda Diyanet İşleri Başkanlığı'nın genel idare içinde yer alarak özel kanunda gösterilen görevleri yerine getireceği ifade edilmiştir. 1982 Anayasası (Md. 136)'nda Başkanlığın görevleri esnasında uyması gereken kıstaslarla ilgili olarak “Genel idare içinde yer alan Diyanet İşleri Başkanlığı, laiklik ilkesi doğrultusunda, bütün siyasi görüş ve düşünüşlerin dışında kalarak ve milletçe dayanışmayı ve bütünleşmeyi amaç edinerek özel kanunda gösterilen görevleri yerine getirir." hükmü yer almıştır. Fakat ülkemizde laikliğin benimsenmesi Hıristiyan Batı dünyasında olduğu gibi tarihsel ve toplumsal sürecin tabii bir neticesi değil bilakis "dinin siyasete alet edilmemesi" maksadıyla belirlenmiş bir hedefin tecellisidir. Bundan dolayı laiklik anlayışı ve uygulamaları, Türkiye'de Batı'daki benzerlerinden farklı olmuştur. Ülkemizde her vesile ile laiklik "din ile devlet işlerinin ayrılması" şeklinde formüle edilmesine rağmen hem dinin devlet kontrolü altında tutulması sağlanmış, hem de sadece şahsi ve vicdani bir mesele olarak kalması istenen dinin, sosyal hayatta marjinal hale getirilmesi istikametinde uygulamalar yapılmıştır. ${ }^{31}$

Şeyhülislamlık kurumunun 15'inci yüzyılın başındaki kuruluş döneminde devlet aklına hâkim olan bakış açısı, zaman içerisinde bu kurumun dünyevi etkinliği gelişirken de daraltılırken de dönemsel ve küçük farklılıklar göz ardı edilmek suretiyle fazlaca değişmemiştir. Temel esas, toplumsal hayatta son derece etkin olan din kurumunu, devletin bekası ve devamı için birleştirici, aynı zamanda meşrulaştırıcı bir unsur olarak işe koşmak ve kontrol etmektir. Gerek kurumun ilk zamanlarında fetret dönemi sonrasındaki Bâtıni-Rafızi akımlar, gerekse tamamen dönüşümün gerçekleştiği milli mücadele esnası ve sonrasında

\footnotetext{
${ }^{31}$ Taş, Türk Halkının Gözüyle Diyanet, 87-89.
} 
çıkardıkları ayaklanmalarla sırf dini gruplar, devletin bekasına karşı tehdit oluşturdukları gerçeğinden hareketle kurumsal din ve devlet arasındaki düzenlemelerin öznesi olmuşlardır.

Osmanlı İmparatorluğu'nun bakiyesi olan Cumhuriyet Türkiye'sinin bu konudaki düzenlemeleri, toplumun farklı dini zaviyelere sahip sırf dini grupların sağlıksız yönlendirmelerinden korunması ve devlet tarafindan daha rasyonel bir anlayışla yönlendirilmesi maksadını taşımaktadır. Cumhuriyet yönetiminin birbiri ardı sıra hayata geçirdiği dini düzenlemeler, hemen öncesinde ayrıcalıklı sosyal statülere sahip olan sırf dini grup önderlerinin sıradanlaşmasına vesile olmuştur. Yasal düzenlemelere rağmen faaliyetlerini daha dar ve kapalı gruplarla gizliden gizliye devam ettiren sirf dini gruplar, zaman içerisinde devletle ilişkilerini çatışma düzleminden uyuşma perspektifine çevirmeye başlamışlardır. Özellikle çok partili rejime geçişten sonra siyasi yelpazenin her kanadı tarafından yandaşlıkları, müntesip daireleriyle birlikte oya tahvil edilmeye çalışılan sırf dini gruplar, ticaretle birlikte siyasetteki etkinliklerini de arttırmaya başlamışlardır. Bu bağlamda zamanla dönüşüme uğrayan söz konusu gruplar, bünyelerinde çağın ve devletin gereklerine ayak uyduracak şekilde yeniden düzenlemelere girişmişlerdir. Bahsi edilen değişimin başlarında grupların muktedir dini elitine has olan devleti İslamileştirme ve gücüne ortak olma çabası gibi gerekçeler, zamanla sadece halisane duygularla gruba intisap etmiş olan bireylerde de sosyal, siyasi, ticari ve bürokratik saadet zincirlerinin bir halkası olma şeklinde tezahür ederek yaygınlık kazanmaya başlamıştır. Ekonomide geçerli olan arz-talep dengesi kuralı, genellikle sosyal değişimi açıklamak için de kullanılabilir. Modern zamanlarda bireyin müntesibi olacağı dini gruptan beklentileri bu yönde olunca, söz konusu yapılar da kendilerini yeni taleplere cevap verecek şekilde düzenlemişlerdir.

Cumhuriyetin henüz olgunlaşmaya başladığı oldukça erken bir dönemde sırf dini grupların politik kaygıların da tetiklediği devlet erkine erişim çabası, siyaset ve bürokraside etkinlik kazanmalarına vesile olmuştur. Dinin ürettiği değerler manzumesinin güce erişim maksadıyla kullanımı, zamanla değerler bütününe de zarar verir hale gelmiştir. İktidar talebinin gerçekleştirilmesi için devletin neredeyse tüm organlarında ve sosyal hayatta her türlü desiseyi yıllarca uyguladıktan sonra kendi devletinin altını oyan ve milletine kast eden bir örneğini, Türk toplumu 15 Temmuz 2016 gibi çok yakın bir tarihte yaşamıştır. İktidar hırsı, ortaya sadece paralel bir devlet yapılanması çıkarmamıs, aynı zamanda paralel bir din de üretmiştir. Bir müntesibin, kendi sırf dini grup halkasına dâhil olmadığı için değer atfetmediği halkını bombalayacak ve rastgele ateş ederek yüzlerce insanın şehit olmasına vesile olacak kadar gözünü karartabileceği dramatik bir şekilde tecrübe edilmiştir. Bu tecrübe ayn zamanda devletin gücüne talip olan bir sırf dini grubun istediğini elde etmek maksadıyla ne tür işbirliklerine girebileceği ve hangi sınırları zorlayabileceğinin de sarih bir göstergesidir. 


\section{SONUÇ}

Bilinen en kadim zamanlardan itibaren insanlığın kutsal dünyaya ilişkin tasavvuru, cari yaşantıyı ve toplumsal hayatı belirleyen temel unsurlardan birisi olagelmiştir. Birey farkında olmasa da kendisinin dışındaki dünyaya bakmak için kullandığı çerçeve, büyük oranda dini düşünce tarafından belirlenmiş bir dindar adam, Mircea Eliade'ın tanımıyla 'homo religiosus'tur. Avrupa'nın dini tarihine bugünkü şeklini vermekle birlikte tüm zamanlar ve medeniyetler için geçerli olan 'cuius regio, eius religio' temel ilkesi, din-devlet ilişkilerinin yapısını anlamak için anahtar kavramdır. İlke, iktidara sahip olanın, hükümranlık alanında geçerli dini belirleyeceğini anlatır. Dünyanın birçok farklı coğrafyasında hafızalara kazınmış, din ve mezhep savaşlarının ya da irili ufaklı göçlerin arka planında bu temel yasanın etkilerini görmek mümkündür.

İktidarı elinde bulunduranın dini belirleme ayrıcalığı bir gerçeklik olmakla birlikte, yeterince kurumsallaştıkları takdirde dini yapıların da iktidarı belirleme gücüne kavuşacağı yadsınamaz. Çalışmanın ilk örneği olan ABD, yakın geçmişte kendi ülkelerinin dini ötekileri olan grupların hicret ederek sığındıkları bir liman olmasına rağmen zamanla güçlenen söz konusu grupların iktidar oyunlarına sahne olmaya devam etmesi açısından belirgin bir örnektir. ABD, aynı zamanda dini ve etnik renkliliğin toplumsal bir problem haline gelmesini engellemek üzere devleti kutsallaştırarak bir sivil din inşasına girişmiştir.

Din savaşları konusunda yeterince problemli bir tarihe sahip olmasına ve bu tecrübeye dayalı laik söylemler geliştirmelerine rağmen durumun farklı olmadığ 1 Avrupa ülkelerinin büyük çoğunluğunda, muktedirin dini anayasal güvence altına alınmış ve ayrıcalıklı hale getirilmiştir. Gayet tabiidir ki ayrıcalık kazanmış olan kurumsal dinin temsilcileri de bunu iktidar temelinde kullanma istidadını taşırlar. Benzer durum dinle kavgalı bir komünist ideolojiyi benimsemiş olan Sovyet Rusya için dahi geçerlidir. Ortodoks Hıristiyanlığın, çok kısa süre zarfında gölgede kalmış olsa da tıpkı Çarlık Rusya'sında olduğu gibi ihtişamlı zamanlarına dönmek için fazla beklemesi gerekmemiştir.

Türkiye Cumhuriyeti'nin kurucu aklı da küllerinden neşet ettiği Osmanlı İmparatorluğu'nda olduğu gibi din kurumunun toplumsal yapıdaki etki ve öneminin farkındadır. Aynı zamanda, öncülünden farklı olarak dinin devlet yapısındaki etkinliğinin azaltılması gerektiği düşüncesi mevcuttur. Hayata geçirilen diğer düzenlemelerle birlikte, siyasetin dini yapılardan, kurumsal dinin de siyasetten elini çekmesi hususundaki zarurete inanılmaktadır. Bu minvalde yapılan idari ve bürokratik düzenlemeler çok partili siyasi hayata geçişten itibaren yavaş yavaş da olsa etkilerini kaybetmeye, dini gruplar siyasetle hemhal olmaya, devlet teşkilatı içerisinde güç kazanmaya başlamıştır. Nihayetinde söz 
konusu gruplar ve iktidar taleplerinin devlet ve toplum üzerindeki yapı bozum etkisi, bunlardan birisi olan FETÖ'nün darbe girişimiyle telafisi güç bir şekilde tecrübe edilecektir.

Netice olarak geleneksel, modern ya da postmodern olmak üzere toplumsal yapılara, kurumsal dini yapıların güç ve etkilerine, devlet mekanizmalarının ulusal ve uluslararası arenadaki siyasi öngörülerine göre değişmekle birlikte, kurumsal dini yapılarla devletler arasındaki ilişkinin geçmişte olduğu gibi bundan sonra da karmaşıklaşmak suretiyle devam edeceğini söylemek mümkündür.

\section{KAYNAKÇA}

Aktay, Yasin. “Amerika'da Din Devlet İlişkileri ve Dini Cemaatlerin Etkisi”. Din ve Devlet İlişkileri Farklı Modeller, Konseptler ve Tecrübeler. 29-48. Ankara: Konrad Adenauer Vakfı Yayını, 2003.

Alkan Özcan, Sevinç. Rusya ve Polonya'da Din, Kimlik, Siyaset. İstanbul: Küre Yayınları, 2012.

Bauman, Gerd. Çokkültürlülük Bilmecesi, Ulusal, Etnik ve Dinsel Kimlikleri Yeniden Düşünmek. Trc. Işıl Demirakın. Ankara: Dost Kitabevi Yayınları, 2006.

Brzezinski, Zbigniew. Büyük Çöküş. Trc. Gül Keskil-Gülsev Pakkan. Ankara: Türkiye İş Bankası Kültür Yayınları, 1997.

Calhoun, Craig. Milliyetçilik. Trc. Bilgen Sütçüoğlu. İstanbul: Bilgi Üniversitesi Yayınları, 2012.

Çaha, Ömer. Bitmeyen Beraberlik Modern Dünyada Din ve Devlet. İstanbul: Timaş Yayınları, 2008.

Dualı, Şir Muhammed. "Rusya Federasyonu'nda Din Eğitimi Meselesi”. Avrasya Incelemeleri Dergisi (AVID) 2/1 (2013): 219-245.

Erşahin, Seyfettin. Türkistan'da İslam ve Müslümanlar. Ankara: İlahiyat Vakfı Yayınları, 1999.

Imıl, Muhittin. Ulus İnşa Sürecinde PKK ve Din İlişkisi. Doktora Tezi, Süleyman Demirel Üniversitesi, 2016.

İbn, Haldun. Mukaddime. Trc. Süleyman Uludağ. İstanbul: Dergâh Yayınları, 2007.

İmga, Orçun. Amerika'da Din ve Devlet Tarihî ve Felsefî Temeller. Ankara: Liberte Yayınları, 2010. 
İpşirli, Mehmet. "Şeyhülislâm”. Türkiye Diyanet Vakfı İslam Ansiklopedisi. 39: 91-96. Ankara: TDV Yayınları, 2010.

Kahraman, Mehmet. “Avrupa Birliği Ülkelerinde ve Türkiye'de Laiklik”. Mustafa Kemal Üniversitesi Sosyal Bilimler Enstitüsü Dergisi 5/9 (2008): 57-77.

Roy, Olivier. Yeni Orta Asya Ya da Ulusların İmal Edilişi. Trc. Mehmet Moralı. İstanbul: Metis Yayınları, 2009.

Sevim, Medine - Gündüz, Turgay. “Türkiye'de Cumhuriyet Dönemi Din Eğitimi ve Öğretimi Kronolojisi". DEM Dergi 1/2 (2007): 64-71.

Somuncuoğlu, Anar. "Rus Ortodoks Kilisesi'nin Eski Sovyet Alanındaki Misyonu". Karadeniz Araştırmaları Dergisi 2 (Yaz 2004): 93-107.

Şencan, Hüdai. "Bazı Avrupa Ülkelerinde Din ve Devlet İlişkisi Raporu”. TBMM Araştırma Merkezi, 2011. Erişim: 3 Haziran 2019

https://anayasa.tbmm.gov.tr/docs/bazi_avrupa_devletlerinde_din_ve_devlet_iliskileri .pdf

Taş, Kemaleddin. Türk Halkının Gözüyle Diyanet. Ankara: İz Yayıncllık, 2002.

Taş, Kemaleddin. “Osmanlı Yönetim Sisteminde Şeyhülislamlık Kurumu -Sosyolojik Bir Çözümleme-". Süleyman Demirel Üniversitesi Sosyal Bilimler Dergisi 1/1 (2005): 81-101.

Tombak, Fatma. “20. Yüzyıl Sovyet Rusya'sında Din, İslamiyet ve Nüfus Üzerine Bir Değerlendirme". History Studies 3/2 (2011): 359-370.

Yıldırım, Onur. "Amerika'da Dinin Siyaset Üzerindeki Etkisi”. Ekonomi İşletme Siyaset ve Uluslararası İlişkiler Dergisi JEBPIR 1/2 (2015): 91-108. 